\title{
PENGARUH REVITALISASI PRODUK WISATA TERHADAP PREFERENSI MENGUNJUNGI LEMBAH BOUGENVILLE RESORT \\ (Survei pada Pengunjung Lembah Bougenville Resort Kecamatan Lembang Kabupaten Bandung Barat)
}

\author{
Kariza Devia Gantini \\ HP. Diyah Setiyorini \\ Manajemen Pemasaran Pariwisata FPIPS UPI
}

\begin{abstract}
Bougenville Valley Resort is a tourist attraction in the Cibodas village, Lembang, West Bandung District. Bougenville Valley Resort has a tourist attraction in the form of a very beautiful valley. Despite this growth in the number of visits in the Valley Bougenville Resort has fluctuating percentage, due Bougenville Valley Resort experience landslide disasters in 2007 with a percentage decrease of $10.65 \%$ and decreased again in 2009. One of the efforts to improve and restore the number of visitors came to the Valley Bougenville Resort, is to do the revitalization of tourism products consisting of revitalization tourist attractions, revitalization amenitas and revitalization of accessibility that may affect the interest of tourists to visit a tourist destination (Nindyo Suwrano: 2008). The purpose of this study was 1) to obtain findings regarding the revitalization of the tourism product in Bougainville Valley Resort 2) To obtain findings regarding preferences visited Bougainville Valley Resort 3) In order to obtain a model of the revitalization of the tourism product of the preference visited Bougainville Valley Resort. This research is descriptive and verification, because the method used is explanatory survey method using ordinal. Teknik scale analysis used in this study is the analysis of the path (path analysis), the technique of using systematic random sampling through cross sectional method with samples taken as many as 100 visitors. The study of the hypothesis shows that the revitalization of the tourism product consists of tourist attractions, amenitas and accessibility has direct and indirect influence significantly to visit the Valley Bougenville Resort preference of 56.8\%, while the remaining $43.2 \%$ is explained by other variables not examined in this study. Suggestions for tourist attraction Bougenville Valley Resort is a further enhance other programs like promotion to the level of preference visited Bougainville Valley Resort better and cooperate with government and private parties.
\end{abstract}

Keywords: Tourism Product Revitalization, Visiting Preferences

\section{PENDAHULUAN}

Saat ini kegiatan pariwisata dikategorikan ke dalam kelompok industri terbesar dunia (the world's largest industry) dan memiliki prospek yang menjanjikan bahkan memberikan peluang besar. Berbagai negara termasuk Indonesia turut menikmati dampak dari peningkatan pariwisata dunia. Indonesia merupakan salah satu negara yang banyak memiliki kekayaan alam yang berpotensi untuk dapat dikembangkan menjadi daerah tujuan wisata.

Pariwisata adalah suatu perjalanan yang dilakukan orang untuk sementara waktu, yang diselenggarakan dari suatu tempat ke tempat lain meninggalkan tempatnya semula, dengan suatu perencanaan dan dengan maksud bukan berusaha atau mencari nafkah di tempat yang dikunjungi, tetapi semata-mata untuk menikmati kegiatan pertamasyaan dan rekreasi atau untuk memenuhi keinginan yang beraneka ragam (Richard Sihite dalam Marpaung \& Bahar, 2000 : 46-47). Pariwisata menurut (Undang-Undang No.10 Tahun 2009 dalam Muljadi, 2009 : 9) adalah berbagai macam kegiatan wisata dan didukung berbagai fasilitas serta layanan yang disediakan oleh masyarakat, pengusaha, pemerintah, dan pemerintah daerah.

Sumberdaya alam hayati dan ekosistemnya yang berupa keanekaragaman flora, fauna dan gejala alam dengan keindahan pemandangan alamnya merupakan anugerah Tuhan Yang Maha Esa. Potensi sumberdaya alam dan ekosistemnya ini dapat dikembangkan dan dimanfaatkan sebesar- 
besarnya bagi kesejahteraan rakyat dengan tetap memperhatikan upaya konservasi. Sumberdaya alam yang dapat dimanfaatkan sebagai pelestarian alam dan sekaligus sebagai daya tarik wisata alam, adalah gunung, taman laut, sungai, pantai, flora termasuk hutan, fauna, air terjun, danau dan pemandangan alam. Keindahan alam yang dimiliki oleh Indonesia itulah yang membuat banyak wisatawan yang ingin berkunjung ke Indonesia. Salah satu wilayah di Indonesia yang banyak dikunjungi wisatawan asing maupun domestik yaitu Jawa Barat. Jawa Barat memiliki keindahan alam yang kaya dan indah, pegunungan, lautan, keberadaan heritage yang bernilai seni dan bernilai sejarah tinggi, kerajinan dan kesenian yang khas, pusat jajanan dan panganan serta keramahan masyarakat yang merupakan potensi pariwisata yang dimiliki Jawa Barat. Provinsi Jawa Barat memiliki 25 Kabupaten yang memberikan alternatif pilihan berwisata yang cukup variatif. Salah satu Kabupaten yang sedang berkembang dengan kepariwistaannya adalah Kabupaten Bandung Barat. Kabupaten yang terletak di sebelah Utara Kota Bandung ini memiliki potensi yang cukup besar untuk mengembangkan kegiatan kepariwisataannya. Kabupaten Bandung Barat memiliki potensi pariwisata yang cukup besar untuk dikembangkan dan dilestarikan.

Salah satu kecamatan yang memiliki potensi cukup besar dalam bidang kepariwisataan dan menjadi primadona di Kabupaten Bandung Barat adalah Kecamatan Lembang. Kecamatan yang terletak di sebelah utara Kota Bandung ini memiliki beberapa daya tarik wisata unggulan diantaranya adalah daya tarik wisata alam seperti Gunung Tangkuban Perahu, air terjun Maribaya, wisata kuliner seperti sate kelinci dan ketan bakar, serta wisata agro yang pada saat ini merupakan salah satu keunggulan dari Kecamatan Lembang.

Kawasan di Kecamatan Lembang yang memiliki banyak daya tarik wisata yang sangat mengandalkan potensi alamnya yang besar adalah Desa Cibodas, desa dengan udara yang sejuk serta memiliki pemandangan yang indah ini terletak di sebelah timur Kecamatan Lembang.

Berdasarkan sumber data Desa Cibodas jumlah kunjungan yang datang ke Desa Cibodas semenjak bertambahnya beberapa daya tarik wisata menyebabkan bertambahnya jumlah wisatawan yang berkunjung ke Desa Cibodas. Peningkatan tingkat kunjungan ke Desa Cibodas ini sebagian besar dikarenakan beragamnya daya tarik wisata sehingga dijadikan sebagai preferensi (pilihan) oleh wisatawan.

Keunikan yang dimiliki oleh daya tarik wisata di Desa Cibodas tersebut menjadi pilihan (preferensi) ketika pengunjung akan melakukan kunjungan wisata. Penetapan preferensi tersebut didasarkan oleh beberapa faktor yang mungkin akan dijadikan sebagai pertimbangan, diantaranya adalah motivasi kunjungan, kesukaan, lokasi untuk menempuh objek wisata, aksesibilitas, fasilitas dan lain sebagainya. Wisatawan memilih suatu daya tarik wisata berdasarkan keunikan-keunikan yang dimiliki oleh daya tarik tersebut sehingga sangat dibutuhkan produk wisata yang baik untuk ditawarkan kepada wisatawan karena hal itu akan sangat mempengaruhi keputusan wisatawan dalam memilih (preferensi) untuk mengunjungi suatu daya tarik wisata. Desa Cibodas menawarkan daya tarik wisata yang cenderung sama karena pada umumnya menawarkan keindahan alam yang dimilikinya sehingga suatu daya tarik wisata harus memberikan sesuatu yang berbeda agar wisatawan lebih memilih daya tarik wisata tersebut.

Suparno Saputra (2010) dalam jurnal Pengaruh Produk terhadap Preferensi Konsumen dalam Pembelian, menyatakan bahwa "produk yang berbeda atau unik akan menguasai pasar dan memenangkan persaingan sesuai dengan pendapat Lewwit The way company manages its marketing can become the most powerful form of differensiasion (Oddrun Bjorklund, 2006:6). Tidak ada perusahaan yang dapat memenangkan persaingan jika produk yang ditawarkan sama dengan produk lain (Kotler, 2005:338), adapun pengertian preferensi itu sendiri adalah alasan mengapa konsumen harus memilih produk tersebut (Uswatun Chasanah, 2003:5). Keunikkan yang ditawarkan oleh suatu daya tarik wisata tidak hanya harus membuat sesuatu yang baru atau menyimpang sehingga berbeda dengan daya tarik wisata yang lain tetapi dapat dilakukan dengan cara memunculkan kembali (revitalisasi) suatu produk yang sudah mati atau sedikit peminatnya menjadi muncul 
kembali dan dinikmati oleh para pengunjung karena hal tersebut mempengaruhi keputusan pemilihan (preferensi) wisatawan.

Berdasarkan penjelasan di atas maka dapat dikatakan bahwa preferensi wisatawan merupakan pertimbangan keputusan yang dipengaruhi oleh berbagai faktor, baik itu faktor selera, motivasi, fasilitas, lokasi, aksesibilitas, tarif harga serta jam kunjungannya (diadaptasi dari Stanton 1996:165).Faktor-faktor pemilihan daya tarik wisata tersebut dijadikan patokan ketika wisatawan disuguhkan pada beberapa pilihan jenis daya tarik di Desa Cibodas.Berdasarkan beberapa daya tarik tersebut terdapat salah satu daya tarik wisata yang dijadikan sebagai preferensi ketika melakukan kunjungan.

Daya tarik wisata yang berada di Desa Cibodas Kecamatan Lembang Kabupaten Bandung Barat yang merupakan salah satu preferensi adalah daya tarik wisata Lembah Bougenville Resort.

Taman wisata Lembah Bougenville Resort ini memiliki pemandangan alam yang menarik berupa sebuah lembah yang indah serta objekobjek spesifik lainnya seperti udara yang segar dan lokasi yang menunjang sehingga Lembah Bougenville Resort melengkapinya dengan sarana dan prasarana yang dapat mendukung keindahan tempat itu sendiri seperti arena bermain anak, restaurant, kolam ikan, taman burung hanggar, pemancingan, area outbound, cottage dan area penjualan sayuran yang kini banyak diminati oleh para wisatawan.

Pada beberapa tahun jumlah pengunjung yang datang ke Lembah Bougenville Resort mengalami penurunan presentase.

Terjadinya penurunan jumlah pengunjung ke Lembah Bougenville Resort pada tahun 2010 menurut pengelola Lembah Bougenville Resort disinyalir salah satu kendalanya yaitu banyaknya para pesaing di kawasan desa Cibodas yang sekarang banyak bermunculan dengan menghadirkan produkproduk yang lebih bervariatif, tidak membosankan dan dapat memberikan jasa yang baik serta faktor alam yang cukup mempengaruhi, hal ini mempengaruhi preferensi pengunjung untuk mengunjungi Lembah Bougenville Resort. Fasilitas yang beragam dan penawaran jasa yang bervariasi cukup menarik pengunjung untuk mengunjungi daya tarik wisata tersebut.
Penurunan jumlah pengunjung yang terjadi di Lembah Bougenville Resort apabila terus terjadi akan mengakibatkan kerugian yang cukup besar bagi pihak Lembah Bougenville Resort. Pemasukan yang didapat akan berkurang karena akan banyak pengunjung yang lebih memilih daya tarik wisata lain dibandingkan mengunjungi daya tarik wisata Lembah Bougenville Resort. Selain pemasukan yang didapat akan berkurang, hal terburuk yang akan terjadi adalah terjadinya kebangkrutan. Ini dapat menjadi acuan pihak manajeman Lembah Bougenville Resort untuk lebih meningkatkan segala hal baik itu berupa fasilitas, program kerja dan cara kerja manajemen agar jumlah pengunjung yang datang ke Lembah Bougenville Resort meningkat kembali bahkan melebihi tahun-tahun sebelumnya.

Bermunculannya daya tarik wisata baru di kawasan Desa Cibodas pada mulanya cukup mempengaruhi tingkat kunjungan di Lembah Bougenville Resort namun hal itu tidak berlangsung lama karena pihak Manajemen Lambah Bougenville Resort melakukan beberapa upaya revitalisasi produk dalam mempertahankan produk dan jasa yang ditawarkannya. Menururt Gamal Suwantoro (2004:48) produk wisata merupakan gabungan dari berbagai komponen, antara lain : atraksi suatu daerah tujuan wisata, fasilitas/amenitas yang tersedia, aksesibilitas ke dan dari daerah tujuan wisata.

Lembah Bougenville Resort akan terus melaksanakan perbaikan manajemen serta melaksanakan perubahan pada produk dan jasanya untuk menarik lebih banyak pengunjung yang diharapkan dapat mengurangi beragam kendala yang dihadapi Lembah Bougenville Resort. Setiap perusahaan harus menciptakan strategi yang akan membantu menunjang, meningkatkan dan mempertahankan posisi produk tersebut dalam pasar sasarannya. Strategi revitalisasi merupakan salah satu keputusan penting yang dapat dilakukan oleh Lembah Bougenville Resort melalui produk wisata yang merupakan suatu alat utama untuk mencapai posisi tertentu dalam melaksanakan fungsi yang diharapkan. Revitalisasi merupakan upaya untuk memvitalkan kembali suatu kawasan yang dulunya pernah hidup, akan tetapi mengalami kemunduran. Revitalisasi produk wisata dapat digunakan untuk mengukur 
seberapa besar wisatawan memilih (preferensi) Lembah Bougenville Resort sebagai tujuan kunjungannya. Menurut Nindyo Suwarno (2008:414) pengembangan revitalisasi suatu kawasan yang meliputi analisis produk wisata dapat mempengaruhi minat wisatawan untuk mengunjungi suatu tujuan wisata.

Revitalisasi produk wisata dapat menentukan keputusan pengunjung dalam memilih daya tarik wisata mana yang akan dikunjungi, suatu daerah tujuan wisata akan dapat menarik minat pengunjung apabila daerah tujuan wisata tersebut dapat menyajikan produk wisata yang baik dan unik. Semakin baik dan unik produk wisata yang diberikan oleh suatu daya tarik wisata, maka akan lebih banyak pengunjung yang datang berkunjung ke daya tarik wisata tersebut yang nantinya akan meningkatkan jumlah pengunjung ke daya tarik wisata tersebut (Sayid Abdul Karim 2010:2).

Lembah Bougenville Resort terus berusaha merevitalisasi produk wisata yang ditawarkannya agar dapat menarik minat pengunjung untuk mengunjungi Lembah Bougenville Resort. Melalui revitalisasi produk wisata yang baik akan meningkatkan preferensi (pilihan) mengunjungi Lembah Bougenville Resort. Berdasarkan latar belakang di tersebut, maka perlu dilakukan penelitian oleh penulis dengan judul "Pengaruh Revitalisasi Produk Wisata Terhadap Preferensi mengunjungi Lembah Bougenville Resort" (Survei pada Pengunjung Lembah Bougenville Resort di Desa Cibodas).

\subsection{Rumusan Masalah}

1. Bagaimana revitalisasi produk wisata yang terdapat di Lembah Bougenville Resort?

2. Bagaimana gambaran preferensi mengunjungi Lembah Bougenville Resort?

3. Bagaimana pelaksanaan revitalisasi produk wisata terhadap preferensi mengunjungi Lembah Bougenville Resort?

\section{KERANGKA PEMIKIRAN}

Pemasaran merupakan suatu sistem total dari kegiatan bisnis yang dirancang untuk merencanakan, menentukan harga, promosi dan mendistribusikan barang-barang yang dapat memuaskan keinginan dan mencapai pasar sasaran serta tujuan perusahaan. Hal itu pula yang terjadi dalam industri pariwisata. Pemasaran pariwisata merupakan proses manajerial oleh suatu individu dan kelompok untuk dapat memperoleh apa yang mereka perlukan dan inginkan melalui penciptaan dan pertukaran produk dan nilai dengan individu atau kelompok lainnya (Kotler at al 2009:45).

Pemasaran merupakan fungsi manajemen yang mamiliki hubungan yang tinggi dengan lingkungan ekternal, perusahaan harus efektif dalam menciptakan nilai pelanggan kepada pasar sasaran dibandingkan dengan pesaing. Kotler dan Keller (2009:62) mengemukakan bauran pemasaran adalah seperangkat alat pemasaran yang digunakan perusahaan untuk mengejar tujuan pemasarannya. Bauran pemasaran terdiri dari segala hal yang dapat dilakukan oleh sebuah perusahaan untuk mempengaruhi konsumen dalam melakukan pembelian produk sedangkan menurut Oka A Yoeti (1996:2) bauran pemasaran adalah segala faktor yang dapat dikuasai dan dipegang oleh manajer pemasaran untuk mempengaruhi permintaan akan barangbarang dan jasa hasil produksi suatu peusahaan. Menurut Internasional Union of Official Travel Organization (IUOTO) dalam Oka A. Yoeti (1996:6) menjelaskan bahwa bauran pemasaran terdiri dari unsur-unsur :

1. Product Mix

Product is the range of attractions and associated amenities, which are to be sold in the markets.

2. Distribution Mix

Distribution mix adalah semua perantara (intermediaries) yang beroperasi dalam pasar, termasuk perusahaan angkutan yang secara bersama melayani wisatawan bila mereka membeli suatu paket wisata (package tour) dan kemudian membawanya ke daerah tujuan wisata.

3. Communication Mix

The process by which the tourist product af a country is brought to the attraction of:

a. Potential customer

b. Organizations who directly or indirectly can influence the attitude of those potential customers towards the country.

c. Intermediaries in the market including the transport concerns, who collectively provide the distribution mix, by which the customers buys his travel and physically gets to his destination. 
4. $\quad$ Service Mix

Pelayanan terpadu (service mix) yaitu memberikan pelayanan kepada wisatawan dengan memuaskan, dimulai semenjak wisatawan membayar harga paket wisata sampai ia menikmati perjalanan itu di daerah tujuan wisata dan akhirnya kembali ke rumah tempat di mana ia biasa tinggal.

Selanjutnya IUOTO dalam Oka a. Yoeti (1996:9) mengatakan bahwa:

The service mix is composed of various services provided which are designed to asset the visitor in having a more enjoyable holiday and in main consist of information offices, complaints investigations, guide and surveillance of the standards of the total tourist product.

Pelayanan terpadu adalah susunan dari bermacam-macam pelayanan yang disediakan dan direncanakan untuk membantu para pengunjung dalam memperoleh kesenangan pada waktu mereka berlibur.

Morrison dalam David Weaver \& Laura Lawton (2006:219) menjelaskan marketing mixlebih terperici, yaitu:

1. Place

Place merupakan hal pokok dalam industri pariwisata karena wisatawan harus melakukan perjalanan menuju destinasi untuk menkonsumsi objek wisata.

2. Product

Product merupakan komponen yang meliputi hasil dari suatu barang dan jasa yang disediakan untuk wisatawan.

3. People

People dalam jasa pariwisata merupakan penyedia jasa yang melayani wisatawan. People sedikitnya memiliki tiga hal yaitu service personnel, the tourist themselves dan local resident.

4. Price

Price merupakan elemen penting dalam marketing mix karena harga merupakan faktor yang dapat menarik wisatawan berkunjung ke suatu destinasi.

5. Packaging

Packaging berarti mengelompokkan dua elemen atau lebih dari tourism experience ke dalam satu produk.
Programming memiliki kaitan dengan packaging yang melibatkan event special, aktivitas atau program suatu produk untuk membuatnya lebih beranekaragam dan lebih menarik.

7. Promotion

Promosi merupakan upaya untuk meningkatkan permintaan melalui pertimbangan kebutuhan, nilai dan sikap pasar atau segmen target pasar.

8. Partnership

Suatu hubungan yang dijalin oleh bisnis sejenis maupun tidak sejenis yang menciptakan benefit bagi pihak-pihak tersebut.

Rambat Lupiyoadi dan A. Hamdani (2008:63) menyatakan bahwa bauran pemasaran jasa terdiri dari tujuh faktor sebagai berikut:

1. Products, produk merupakan bentuk penawaran organisasi jasa yang ditunjukan untuk mencapai tujuan organisasi melalui pemuasan kebutuhan dan keinginan pelanggan.

2. Price, keputusan bauran harga berkenaan dengan kebijakan strategis dan taktis, seperti tingkat harga, struktur diskon, syarat pembayaran, dan tingkat diskriminasi harga di antara berbagai kelompok pelanggan.

3. Promotion, bauran promosi tradisional meliputi berbagai metode untuk mengkomunikasikan manfaat jasa kepada pelanggan potensial dan aktual. Metodemetode tersebut terdiri atas periklanan, promosi penjualan, direct marketing, personal selling, dan public relations.

4. Place, keputusan distribusi menyangkut kemudahan akses terhadap jasa bagi para pelanggan potensial. Keputusan ini meliputi keputusan lokasi fisik (misalnya keputusan mengenai di mana sebuah hotel atau restoran harus didirikan).

5. People, bagi sebagian besar jasa, orang merupakan unsur vital dalam bauran pemasaran. Bila produksi dapat dipisahkan dengan konsumsi, sebagaimana dijumpai dalam kebanyakan kasus pemasaran barang manufaktur, pihak manajemen biasanya dapat mengurangi pengaruh langsung sumber daya manusia terhadap output akhir yang diterima pelanggan.

6. Programming 
6. Process, proses produksi atau operasi meruapakn faktor penting bagi konsumen high-contact services, yang seringkali juga berperan sebagai co-producer jasa bersangkutan.

7. Customer Service, makna layanan pelanggan berbeda antar organisasi. Dalam sektor jasa, layanan pelanggan dapat diartikan sebagai kualitas total jasa yang dipersepsikan oleh pelanggan.

Berdasarkan penjelasan mengenai marketing mix yang dijelaskan di atas, maka dapat diketahui bahwa marketing mix terdiri dari beberapa komponen.Beberapa komponen yang terdapat di dalam marketing mix tersebut dapat menentukan permintaan dalam suatu kegiatan perusahaan.Produk merupakan salah satu komponen dalam marketing mix yang kemudian dapat berkembang menjadi revitalisasi produk wisata. Menurut Kotler dan Amstrong (2008:266) mengatakan bahwa "Produk adalah semua yang dapat ditawarkan kepada pasar agar dapat menarik perhatian, akuisisi, penggunaan atau konsumsi yang dapat memuaskan suatu keinginan atau kebutuhan".

Dalam arti luas produk tidak hanya barang-barang yang berwujud (tangible) tetapi juga objek-objek fisik, jasa, acara, orang, tempat organisasi, ide atau bauran entitasentitas ini.Sedangkan menururt Kotler \& Keller (2009:58), konsep produk merupakan suatu konsep tertua dalam suatu bisnis.Konsep produk bertujuan untuk menciptakan produk yang dikuasai oleh konsumen dengan kualitas, performance, dan fitur yang baik. Produk dapat dikatakan sebagai suatu rangkaian kegiatan yang bertalian dengan penciptaan sesuatu barang atau jasa dalam bentuk yang diinginkan.

Produk merupakan titik sentral dari kegiatan pemasaran suatu perusahaan, produk dapat berupa barang dan jasa. Industri pariwisata menawarkan produk yang berbeda dengan perusahaan lain yang bergerak pada bidang manufaktur. Produk wisata bukanlah suatu produk yang nyata, produk ini merupakan suatu rangkaian jasa yang tidak hanya mempunyai segi-segi yang bersifat ekonomis, tetapi juga bersifat sosial, psikologis dan alami, walaupun produk wisata itu sendiri sebagian besar dipengaruhi oleh tingkah laku ekonomi.
Berdasarkan beberapa pengertian para ahli tersebut, produk wisata merupakan sesuatu yang dapat dikonsumsi oleh konsumen baik berupa barang berwujud (tangible) maupun tidak berwujud (intangible).Semakin meningkatnya kebutuhan wisatawan mendorong pihak yang terlibat dalam industri pariwisata terus membuat produk wisata. Beberapa pengertian tersebut dipertegas oleh Boud-Bovy dalam jurnal Edwin Fianto (2000:2) mengatakan bahwa produk pariwisata adalah sejumlah komponen yaitu sumber daya yang terdapat pada suatu daerah tujuan wisata, fasilitas yang terdapat di suatu daerah tujuan wisata dan transportasi yang membawa dari tempat asalnya ke suatu daerah tujuan wisata.

Produk merupakan salah satu hal yang sering dipertimbangkan oleh konsumen untuk mengunjungi suatu tujuan sehingga pengembangan produk perlu dilakukan, hal ini dilakukan agar tidak terjadi kebosanan pada konsumen.

Proses pengembangan produk baru dapat didefinisikan sebagai "Satu kumpulan tugas atau langkah-langkah yang menggambarkan cara perusahaan dalam mengubah ide-ide menjadi produk atau jasa untuk dijual" (Kenneth Karel Boyer \& Rohit Verma, 2009:478). Menurut Ted Mininni dalam brandcannel (2008:2) pengembangan produk dapat dikembangkan melalui berbagai cara diantaranya melaui revitalisasi, rejuvinasi dan reformulasi.
a. Revitalisasi
Proses, cara, perbuatan menghidupkan atau menggiatkan kembali suatu hal yang sebelumnya kurang berdaya, usaha-usaha untuk menjadikan sesuatu itu menjadi penting dan perlu.
b. Rejuvinasi
Proses meremajakan kembali secara fisik, rejuvinasi mengurangi hingga meniadakan ciri-ciri penuaan.
c. Reformulasi
Perubahan yang drastis yang dilakukan untuk melakukan suatau perubahan.

Pengertian revitalisasi dapat diartikan menghidupkan kembali suatu kawasan yang sudah mati, meningkatkan kawasan yang sudah hidup, menyuntikan sesuatu yang baru 
(aktivitas dan bangunan) pada suatu kawasan.(Kimpraswil, 2003).

Dikutip dari jurnal Jonny Wongso revitalisasi menurut Departemen Kimpraswil (2002) adalah rangkaian upaya menghidupkan kembali kawasan yang cenderuang mati, meningkatkan nilai-nilai vitalitas yang strategis dan signifikan dari kawasan yang masih mempunyai potensi dan mengendalikan kawasan yang cenderung kacau atau semrawut. Menurut Yulia V Smirnova (2006:1) revitalisasi terdiri dari 3 strategi atau dimensi yang dapat menunjukan revitalisasi yaitu :

a. Menambahkan nilai baru / Adding a New Value

Ini adalah cara untuk mencari peluang kreatif untuk mendefinisikan produk.

b. Reposisi / Repositioning Melibatkan menciptakan posisi kompetitif baru dibenak konsumen.

c. Memperluas Basis / Extending The Base

Meningkatkan tingkat adopsi, tingkat penggunaan atau pasar yang baru masuk, untuk mengetahui kelayakan. Manager produk mengetahui profil pelanggan yang cenderung membeli lebih dari rata-rata atau mengkonsumsi lebih dari rata-rata dan mencari tahu apa yang menyebabkan mereka untuk melakukan itu.

Berdasarkan definisi-definisi revitalisai produk dari beberapa ahli maka dalam penelitian ini digunakan premis menurut Nindyo Suwarno (2008) pengembangan revitalisasi suatu kawasan yang meliputi analisis produk wisata yang terdiri dari revitalisasi atraksi wisata, revitalisasi amenitas dan aksesibilitas yang dapat mempengaruhi minat wisatawan untuk mengunjungi suatu tujuan wisata.

a. Revitalisasi atraksi wisata adalah menghidupkan kembali atraksi wisata yang sudah mati dan meningkatkan kembali atraksi wisata yang sudah ada serta merupakan perombakan salah satu komponen yang terdapat dalam komponen produk wisata dan yang menjadi daya tarik bagi wisatawan untuk mengunjungi suatu daerah tujuan wisata. Menurut Rochajat
Harun (2008:54) Tourist Atraction, yaitu segala sesuatu baik lokasi tempat dan kegiatan yang menjadi daya tarik bagi masyarakat untuk mengunjungisuatu daerah tertentu. Sedangkan menurut Oka A. Yoeti (2009:166) daya tarik wisata adalah apa saja yang dapat ditawarkan kepada mereka bila mereka datang berkunjung pada suatu negara atau daya tarik wisata tertentu. Atraksi merupakan komponen yang paling penting pada suatu destinasi di mana atraksi tersebut merupakan daya tarik bagi wisatawan untuk mengunjungi suatu destinasi.

b. Revitalisasi amenitas menghidupkan kembali amenitas yang sudah mati, meningkatkan kembali amenitas yang sudah ada yang merupakan bagian produk industri pariwisata. Amenitas merupakan komponen pendukung dari kegiatan pariwisata, dimana jasa yang disediakan berupa berbagai fasiltas yang terdapat pada setiap destinasi guna kemudahan pengunjung atau wisatawan. Fungsinya untuk memenuhi kebutuhan wisatawan selama tinggal untuk sementara waktu di destinasi yang dikunjungi. Menurut Oka.A.Yoeti (2002:211) amenitas adalah fasilitas yang dimiliki daerah tujuan wisata, meliputi akomodasi, usaha pengolahan makanan, transportasi, rekreasi dan lain-lain. Sedangkan menurut I Gede Iwan (2007:4) amenitas adalah mempunyai fungsi untuk memenuhi kebutuhan wisatawan selama tinggal untuk sementara waktu di daya tarik wisata yang dikunjungi. Selain faktor atraksi, amenitas juga mempunyai peranan yang sangat besar bagi wisatawan yang akan mengunjungi suatu destinasi. Semakin lengkapnya suatu destinasi mempunyai amenitas atau fasilitas yang lengkap maka semakin banyak pula wisatawan yang mengunjungi destinasi tersebut.

c. Revitalisasi aksesibilitas adalah menghidupkan kembali aksesibilitas yang sudah mati dan meningkatkan kembali aksesibiltas yang sudah ada. 
aksesibilitas bagian produk industri pariwisata yang merupakan sarana pendukung untuk membantu wisatawan agar mudah menjangkau suatu destinasi. Fasilitas yang tersedia agar waktu tempuh dari tempat wisatawan atau pengunjung menjadi lebih mudah dan lebih singkat. Adapun pendapat menurut Oka A. Yoeti (2002:211) aksesibilitas yaitu kemudahan untuk mencapai daerah tujuan wisata tersebut. Sedangkan menurut I Gede Iwan (2007:5) aksesibilitas adalah semua yang dapat member kemudahan kepada wisatawan untuk datang berkunjung pada suatu daerah tujuan wisata. Aksesibilitas termasuk juga dalam komponen produk wisata, faktor ini pun merupakan komponen yang sangat penting agar dapat memudahkan pengunjung atau wisatawan untuk mengunjungi suatu tujuan wisata atau destinasi.

Preferensi atau yang disebut juga selera adalah sebuah konsep yang digunakan pada ilmu sosial, khususnya ekonomi dan manajemen.Ini mengasumsikan pilihan realitas atau imajiner antara alternatif-alternatif dan kemungkinana dari pemeringkatan alternatif tersebut, berdasarkan kesenangan, kepuasan, gratifikasi, pemenuhan dan kegunaan yang ada.Lebih luas lagi, bisa dilihat sebagai sumber dari motivasi. Dalam ilmu kognitif, preferensi individual memungkinkan pemilihan tujuan/goal.

Preferensi wisatawan adalah nilai-nilai bagi wisatawan yang diperhatikan dalam menentukan sebuah pilihan. Dalam kaitan dengan preferensi ini, maka wisatawan akan menggunakan harapannya sebagai standar atau acuan. Dengan demikian, harapan pelangganlah yang melatarbelakangi mengapa dua organisasi pada bisnis yang sama dapat dinilai berbeda oleh pelanggannya. Dalam konteks preferensi wisatawan, umumnya harapan merupakan perkiraan atau keyakinan wisatawan tentang apa yang akan diterimanya.

Uswatun Chasanah dalam jurnal Olvini Tyssia (2010) menyatakan "Preferensi adalah alasan mengapa konsumen harus membeli atau menggunakan produk tersebut'.Preferensi merupakan bagian dari perilaku yang sangat mempengaruhi penetapan pilihan wisatawan di samping hambatan yang ada. Preferensi konsumen lebih mengacu pada bagaimana perasaan seseorang atas sesuatu hal dan apa yang mereka lakukan, sehingga dapat dikatakan sebagai bentuk pernyataan dari rasa ketertarikan wiasatawan atas sesuatu yang mampu menghalangi seseorang mencapai apa yang mereka kehendaki, seperti waktu, pendapatan dan jarak

Menurut Sudibyo (2004:4)

Preferensi wisatawan merupakan nilainlai yang dianut wisatawan dalam menghadapi berbagai bentuk konflik dalam lingkungannya.Konflik ini tidak harus konflik dalam bentuk fisik, namun pengertian konflik yang dimaksudkan meliputi konflik dalam arti perbedaan antara harapan dengan realisasi yang dirasakan dari permasalahan yang dihadapi.

Dalam pengukuran tingkat preferensi wisatawan, data yang diperoleh bersifat subyektif, sesuai dengan jawaban para responden menurut pengalaman dalam menggunakan suatu jenis produk wisata tertentu. Adapun faktor-faktor yang sering kali mempengaruhi pilihan (preferensi) di kalangan konsumen dalam memilih adalah sebagai berikut (diadaptasi dari Stanton 1999:165) :

1. Kenyamanan lokasi

2. Pelayanan yang diberikan

3. Kemudahan aksesibilitas

4. Kelengkapan fasilitas

5. Suasana yang menarik (daya tarik wisata)

6. Kemampuan karyawan

Jam pelayanan (jam kunjungan)

\section{METODE PENELITIAN}

Penelitian ini menggunakan pendekatan ilmu manajemen pemasaran pariwisata, yang menganalisis revitalisasi produk wisata terhadap preferensi mengunjungi.Adapun yang menjadi objek penelitian sebagai independent variabel (variabel bebas) atau variabel $\mathrm{X}$ adalah tanggapan perusahaan mengenairevitalisasi produk wisata yang terdiri dari, revitalisasi atraksi (X1),revitalisasi amenitas (X2),dan revitalisasiaksesibilitas (X3). Sedangkan variable dependent (variable terikat) atau variabel $Y$ yang diteliti yaitu preferensi mengunjungi yang terdiri dari 
lokasi, aksesibilitas, fasilitas, suasana, pelayanan dan kemampuan karyawan.

Pada penelitian ini yang menjadi responden adalah wisatawan umum yang datang ke objek wisataLembah Bougenville Resort. Berdasarkan objek penelitian tersebut, maka akan dianalisis mengenai pengaruh revitalisasi produk wisata terhadap preferensi mengunjungi objek wisata Lembah Bougenville Resort.
Penelitian ini dilakukan satu kali dalam kurun waktu kurang dari satu tahun, maka metode yang dilakukan adalah cross sectional. Metode penelitian ini menggunakan dua jenis penelitian deskriptif dan verifikatif. Berdasarkan jenis penelitiannya yaitu metode penelitian deskriftif dan verifikat maka metode yang digunakan dalam penelitian ini adalah explanatory survey.

TABEL 3.1

OPERASIONALISASI VARIABEL

\begin{tabular}{|c|c|c|c|c|c|}
\hline $\begin{array}{c}\text { Variabel/sub } \\
\text { variabel }\end{array}$ & Konsep Variabel & Indikator & Ukuran & Skala & $\begin{array}{c}\text { No. } \\
\text { angket }\end{array}$ \\
\hline $\begin{array}{l}\text { Revitalisasi } \\
\text { Produk } \\
\text { Wisata } \\
\text { (X) }\end{array}$ & $\begin{array}{l}\text { Menghidupkan } \\
\text { kembali suatu } \\
\text { kawasan yang sudah } \\
\text { mati, meningkatkan } \\
\text { kawasan yang sudah } \\
\text { hidup, menyuntikan } \\
\text { sesuatu yang baru } \\
\text { (aktivitas dan } \\
\text { bangunan) pada suatu } \\
\text { kawasan }\end{array}$ & & & & \\
\hline $\begin{array}{l}\text { Revitalisasi } \\
\text { Atraksi }\end{array}$ & $\begin{array}{l}\text { Perubahan atau } \\
\text { pemunculan kembali } \\
\text { sesuatu yang dapat } \\
\text { ditawarkan kepada } \\
\text { mereka bila mereka } \\
\text { datang berkunjung } \\
\text { pada suatu Negara } \\
\text { atau daya tarik wisata } \\
\text { tertentu. } \\
\text { Nindyo Suwarno } \\
(2008)\end{array}$ & $\begin{array}{l}\text { Atraksi wisata } \\
\text { alam } \\
\text { - Keindahan } \\
\text { panorama } \\
\text { (penempatan } \\
\text { kawasan yang } \\
\text { disesuaikan } \\
\text { dengan } \\
\text { keindahan } \\
\text { panorama) } \\
\text { Atraksi buatan } \\
\text { manusia/ Event } \\
\text { Attraction } \\
\text { - Atraksi } \\
\text { hiburan yang } \\
\text { kreatif } \\
\text { Atraksi } \\
\text { buatan yang } \\
\text { menciptakan } \\
\text { posisi di } \\
\text { benak } \\
\text { konsumen } \\
\text { Terdapat } \\
\text { atraksi yang } \\
\text { membuat } \\
\text { konsumen } \\
\text { ingin }\end{array}$ & $\begin{array}{l}\text { - Tingkat } \\
\text { keindahan } \\
\text { panorama } \\
\text { yang dapat } \\
\text { dinikmati } \\
\text { (penempatan } \\
\text { kawasan } \\
\text { yang baru) } \\
\\
\text { - } \\
\text { Tingkat } \\
\text { atraksi } \\
\text { hiburan yang } \\
\text { kreatif } \\
\text { Tingkat } \\
\text { penciptaan } \\
\text { posisi } \\
\text { benak di } \\
\text { konsumen } \\
\text { Tingkat } \\
\text { kemenarikan } \\
\text { atraksi baru } \\
\text { yang } \\
\text { ditawarkan. }\end{array}$ & $\begin{array}{l}\text { Ordinal } \\
\text { Ordinal }\end{array}$ & III.A.3 \\
\hline
\end{tabular}




\begin{tabular}{|c|c|c|c|c|c|}
\hline & & $\begin{array}{l}\text { menikmatiny } \\
\text { a secara terus } \\
\text { menerus. } \\
\text { Terdapat } \\
\text { atraksi yang } \\
\text { berbeda } \\
\text { dengan daya } \\
\text { tarik wisata } \\
\text { lain. }\end{array}$ & $\begin{array}{l}\text { Tingkat } \\
\text { kemenarikan } \\
\text { atraksi } \\
\text { dibandingkan } \\
\text { daya tarik } \\
\text { wisata lain. }\end{array}$ & & \\
\hline $\begin{array}{l}\text { Revitalisasi } \\
\text { Amenitas }\end{array}$ & $\begin{array}{lr}\text { Perubahan } & \text { atau } \\
\text { pemunculan pada } \\
\text { prasarana atau } \\
\text { fasilitas yang dimiliki } \\
\text { daerah tujuan wisata, } \\
\text { meliputi akomodasi, } \\
\text { usaha pengolahan } \\
\text { makanan, } \\
\text { transportasi, rekreasi } \\
\text { dan lain-lain. Nindyo } \\
\text { Suwarno (2008) }\end{array}$ & 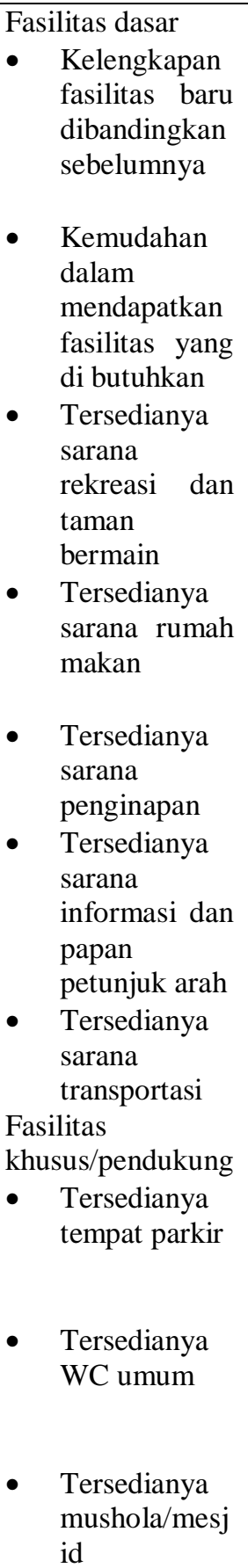 & 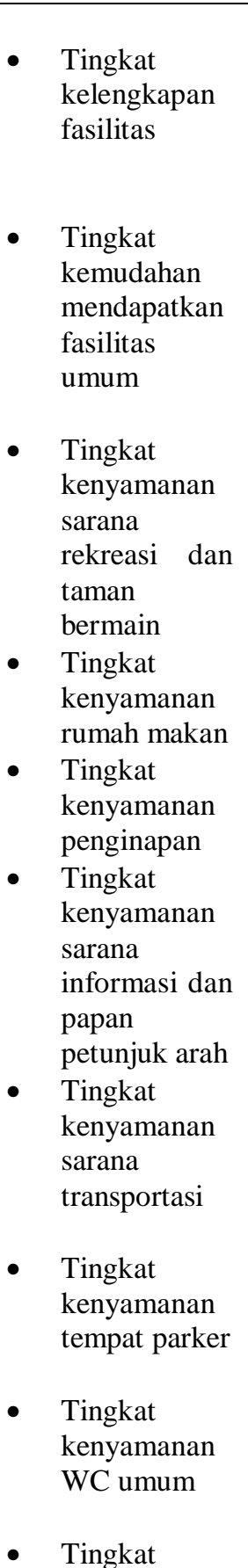 & Ordinal & III.B.7 \\
\hline
\end{tabular}




\begin{tabular}{|c|c|c|c|c|c|}
\hline & & $\begin{array}{l}\text { - Tersedianya } \\
\text { kios } \\
\text { cenderamata }\end{array}$ & $\begin{array}{l}\text { kenyamanan } \\
\text { mushola/mesj } \\
\text { id } \\
\text { Tingkat } \\
\text { kenyamanan } \\
\text { kios } \\
\text { cenderamata }\end{array}$ & Ordinal & III.B.11 \\
\hline $\begin{array}{l}\text { Revitalisasi } \\
\text { Aksesibilitas }\end{array}$ & $\begin{array}{l}\text { Kemudahan dalam } \\
\text { memperoleh atau } \\
\text { mencapai tujuan daya } \\
\text { tarik wisata. Nindyo } \\
\text { Suwarno (2008) }\end{array}$ & $\begin{array}{l}\text { - Kemudahan } \\
\text { menjangkau } \\
\text { ODTW } \\
\text { - Kenyamanan } \\
\text { saat perjalanan } \\
\text { - Efisiensi waktu } \\
\text { yang ditempuh } \\
\text { - Infrastruktur } \\
\text { yang lebih baik } \\
\text { - Ketersediaan } \\
\text { angkutan } \\
\text { umum }\end{array}$ & $\begin{array}{l}\text { - Tingkat } \\
\text { kemudahan } \\
\text { menjangkau } \\
\text { ODTW } \\
\text { - Tingkat } \\
\text { kenyamanan } \\
\text { saat perjalanan } \\
\text { - Tingkat } \\
\text { efisiensi waktu } \\
\text { yang ditempuh } \\
\text { - Tingkat } \\
\text { infrastruktur } \\
\text { yang lebih baik } \\
\text { - Tingkat } \\
\text { kenyamanan } \\
\text { angkutan } \\
\text { umum }\end{array}$ & $\begin{array}{l}\text { Ordinal } \\
\text { Ordinal } \\
\text { Ordinal } \\
\text { Ordinal } \\
\text { Ordinal }\end{array}$ & $\begin{array}{l}\text { III.C.1 } \\
\text { III.C.2 } \\
\text { III.C.3 } \\
\\
\text { III.C.4 } \\
\text { III.C.5 }\end{array}$ \\
\hline $\begin{array}{l}\text { Preferensi } \\
\text { Mengunjungi } \\
\text { (Y) }\end{array}$ & $\begin{array}{l}\text { Preferensi wisatawan } \\
\text { merupakan nilai-nlai } \\
\text { yang } \\
\text { wisatawan danut } \\
\text { menghadapi berbagai } \\
\text { bentuk konflik dalam } \\
\text { lingkungannya. } \\
\text { Konflik ini tidak } \\
\text { harus konflik dalam } \\
\text { bentuk fisik, namun } \\
\text { pengertian konflik } \\
\text { yang dimaksudkan } \\
\text { meliputi konflik } \\
\text { dalam arti perbedaan } \\
\text { antara harapan } \\
\text { dengan realisasi yang } \\
\text { dirasakan } \\
\text { permasalahan yang } \\
\text { dihadapi Sudibyo } \\
(2004: 4)\end{array}$ & & & & \\
\hline $\begin{array}{l}\text { Kenyamanan } \\
\text { Lokasi }\end{array}$ & $\begin{array}{lr}\text { Suatu } & \text { strategi yang } \\
\text { menentukan dimana } \\
\text { dan } & \text { bagaimana } \\
\end{array}$ & - $\quad$ Lokasi & $\begin{array}{ll} & \text { Tingkat } \\
\text { preferensi } \\
\text { berdasarkan }\end{array}$ & Ordinal & IV.A.1 \\
\hline
\end{tabular}




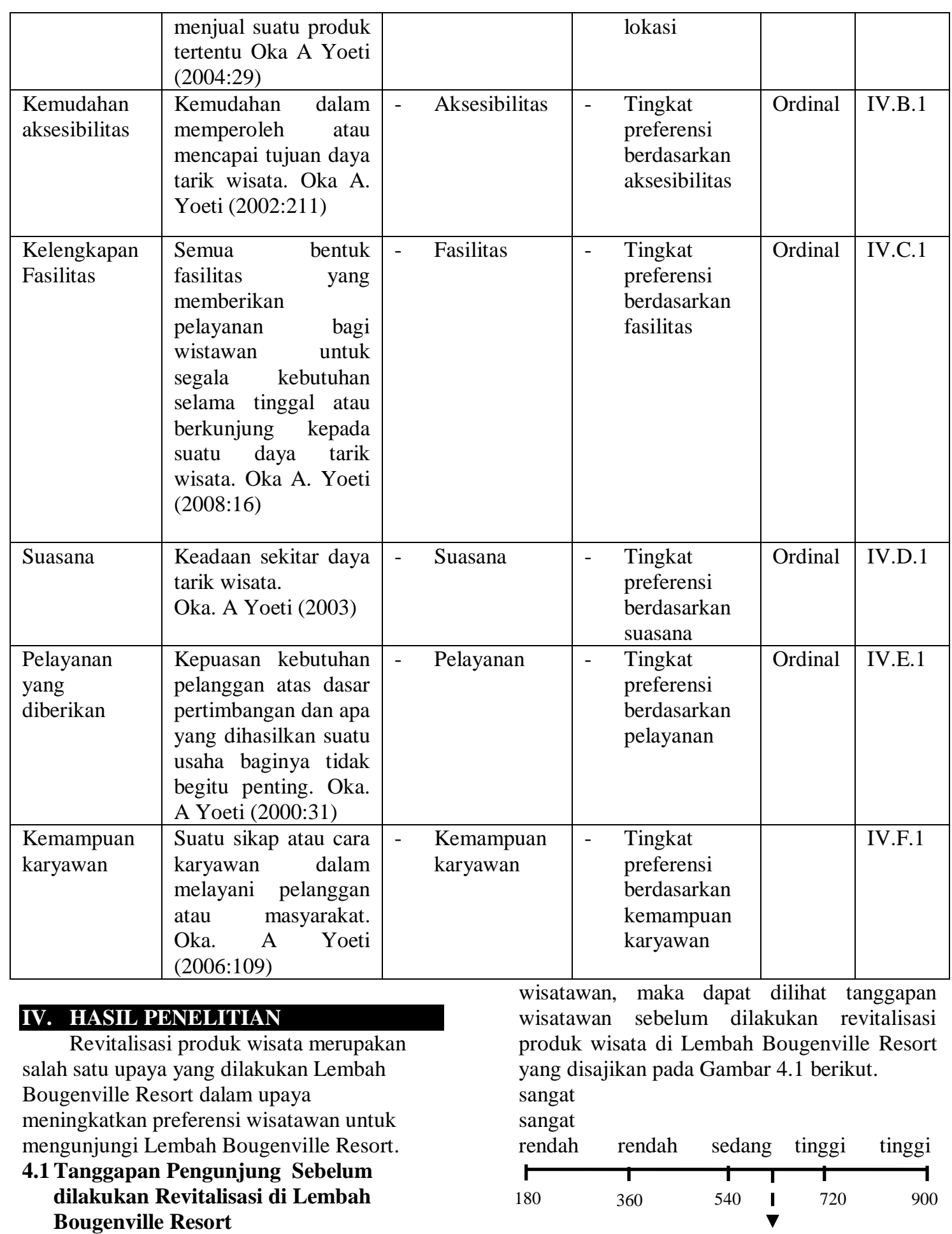

Variabel-variabel penelitian yang diteliti pada penelitian ini yaitu revitalisasi produk wisata dan preferensi mengunjungi.Variabel revitalisasi produk wisata terdiri dari atraksi wisata, amenitas dan aksesibilitas.

GAMBAR 4.1

TANGGAPAN PENGUNJUNG SEBELUM REVITALISASI 
TABEL 4.1

REKAPITULASI HASIL TANGGAPAN PENGUNJUNG SEBELUM DILAKUKAN

REVITALISASI PRODUK WISATA

LEMBAH BOUGENVILLE RESORT

\begin{tabular}{|c|c|c|c|c|}
\hline $\begin{array}{l}\mathbf{N} \\
\mathbf{0 .}\end{array}$ & $\begin{array}{c}\text { Sub } \\
\text { Variabel }\end{array}$ & $\begin{array}{l}\text { Total } \\
\text { Skor }\end{array}$ & $\begin{array}{c}\text { Skor } \\
\text { Rata- } \\
\text { rata } \\
\end{array}$ & $\%$ \\
\hline 1 & $\begin{array}{l}\text { Atraksi } \\
\text { Wisata }\end{array}$ & 1523 & 380,75 & $\begin{array}{c}33,4 \\
2\end{array}$ \\
\hline 2 & Amenitas & 3838 & 383,8 & $\begin{array}{c}33,6 \\
9 \\
\end{array}$ \\
\hline 3 & $\begin{array}{l}\text { Aksesibilit } \\
\text { as }\end{array}$ & 1499 & 374,75 & $\begin{array}{c}32,8 \\
9 \\
\end{array}$ \\
\hline \multicolumn{2}{|r|}{ Total } & 6860 & 1139,3 & 100 \\
\hline
\end{tabular}

\subsection{Tanggapan Pengunjung Terhadap}

Revitalisasi Produk Wisata Setelah

dilakukan Lembah Bougenville Resort

Variabel-variabel penelitian yang diteliti pada penelitian ini yaitu revitalisasi produk wisata dan preferensi mengunjungi.Variabel revitalisasi produk wisata terdiri dari atraksi wisata, amenitas dan aksesibilitas.Berdasarkan hasil pengolahan data dari 100 wisatawan, maka dapat dilihat tanggapan wisatawan mengenai revitalisasi produk wisata yang dilakukan di Lembah Bougenville Resort yang disajikan pada Gambar 4.2 berikut :

\begin{tabular}{|c|c|c|c|c|}
\hline $\begin{array}{l}\text { Sangat } \\
\text { rendah }\end{array}$ & rendah & sedang & tinggi & $\begin{array}{r}\text { Sangat } \\
\text { tinggi }\end{array}$ \\
\hline & & & & \\
\hline 180 & 360 & 540 & $\mathbf{1}^{720}$ & 900 \\
\hline
\end{tabular}

GAMBAR 4.2

TANGGAPAN PENGUNJUNG SETELAH REVITALISASI

4.3 Rekapitulasi Tanggapan Pengunjung terhadap Analisis Revitalisasi Produk Wisata Setelah dilakukanLembah Bougenville Resort

Rekapitulasi mengenai penilaian pengunjung Lembah Bougenville Resort terhadap revitalisasi produk wisata yang dilakukan Lembah Bougenville Resort berada di posisi yang baik. Hal ini dapat dilihat pada Tabel 4.2 berikut
Rekapitulasi mengenai penilaian wisatawan Lembah Bougenville Resort sebelum dilakukan revitalisasi produk wisata berada di posisi yang baik.

TABEL 4.2

REKAPITULASI HASIL TANGGAPAN PENGUNJUNG TERHADAP

REVITALISASI PRODUK WISATA

SETELAH DILAKUKAN LEMBAH BOUGENVILLE RESORT

\begin{tabular}{|c|l|c|c|c|}
\hline $\begin{array}{c}\mathbf{N} \\
\text { o. }\end{array}$ & \multicolumn{1}{|c|}{$\begin{array}{c}\text { Sub } \\
\text { Variabel }\end{array}$} & $\begin{array}{c}\text { Total } \\
\text { Skor }\end{array}$ & $\begin{array}{c}\text { Skor } \\
\text { Rata-rata }\end{array}$ & $\%$ \\
\hline 1 & $\begin{array}{l}\text { Atraksi } \\
\text { Wisata }\end{array}$ & 1635 & 408,75 & $\begin{array}{c}34, \\
28\end{array}$ \\
\hline 2 & Amenitas & 3875 & 387,5 & $\begin{array}{c}32, \\
50\end{array}$ \\
\hline 3 & $\begin{array}{l}\text { Aksesibili } \\
\text { tas }\end{array}$ & 1585 & 396,25 & $\begin{array}{c}33, \\
22\end{array}$ \\
\hline \multicolumn{2}{|c|}{ Total } & $\mathbf{7 0 9 5}$ & $\mathbf{1 1 9 2 , 5}$ & $\mathbf{1 0 0}$ \\
\hline
\end{tabular}
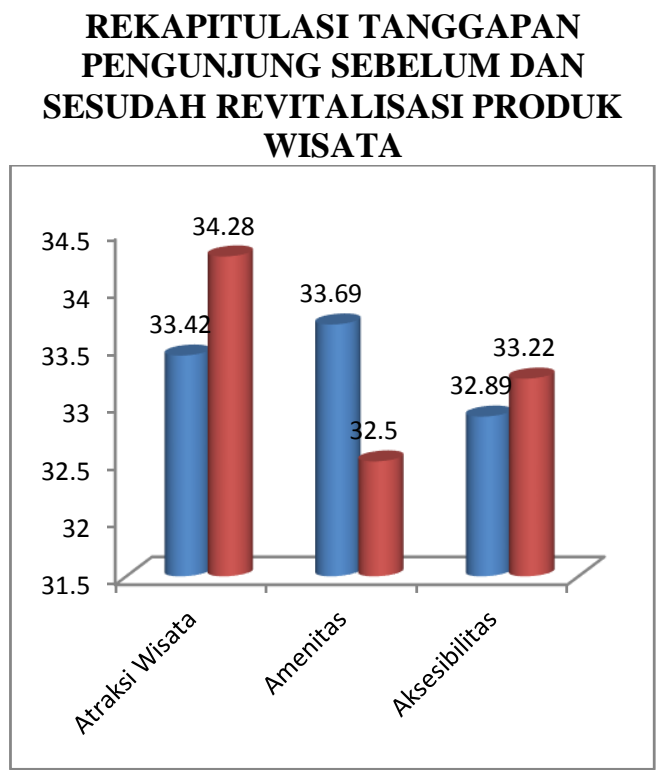

GAMBAR 4.3

Preferensi wisatawan adalah nilai-nilai bagi wisatawan yang diperhatikan dalam menentukan sebuah pilihan, dalam kaitan dengan preferensi maka wisatawan akan menggunakan harapannya sebagai standar atau acuan. Berdasarkan hasil penelitian preferensi mengunjungi dapat dijelaskan melalui tabel di bawah ini. 
TABEL 4.3

REKAPITULASI HASIL TANGGAPAN
PENGUNJUNG TERHADAP PREFERENSI MENGUNJUNGI LEMBAH BOUGENVILLE RESORT

\begin{tabular}{|l|l|l|l|l|}
\hline $\begin{array}{l}\text { N } \\
\text { o. }\end{array}$ & Sub Variabel & $\begin{array}{c}\text { Total } \\
\text { Skor }\end{array}$ & $\begin{array}{c}\text { Skor } \\
\text { Rata- } \\
\text { rata }\end{array}$ & $\mathbf{\%}$ \\
\hline 1 & Lokasi & 403 & 67,16 & $\begin{array}{l}16, \\
77\end{array}$ \\
\hline 2 & Aksesibilitas & 394 & 65,66 & $\begin{array}{l}16, \\
39\end{array}$ \\
\hline 3 & Fasilitas & 420 & 70 & $\begin{array}{l}17, \\
47\end{array}$ \\
\hline 4 & Suasana & 410 & 68,33 & $\begin{array}{l}17 \\
05\end{array}$ \\
\hline 5 & Pelayanan & 375 & 62,5 & $\begin{array}{l}15, \\
60\end{array}$ \\
\hline 6 & $\begin{array}{l}\text { Kemampuan } \\
\text { karyawan }\end{array}$ & 402 & 67 & $\begin{array}{l}16, \\
72\end{array}$ \\
\hline \multicolumn{2}{|l}{ Total } & $\mathbf{2 4 0 4}$ & $\mathbf{4 0 0 , 6 5}$ & $\mathbf{1 0 0}$ \\
\hline
\end{tabular}

Hipotesis: Terdapat Pengaruh Revitalisasi Produk Wisatapada Preferensi Mengunjungi Lembah Bougenville Resort Pengujian hipotesis dilakukan untuk menguji besarnya pengaruh revitalisasi produk wisata $(\mathrm{X})$ yang terdiri dari atraksi wisata $\left(\mathrm{X}_{1}\right)$, amenitas $\left(\mathrm{X}_{2}\right)$ dan aksesibilitas $\left(\mathrm{X}_{3}\right)$ terhadap preferensi mengunjungi (Y) dilakukan dengan menggunakan uji statistik analisis jalur (path analysis). Data yang digunakan dalam pengolahan data pada penelitian ini adalah data sesudah dilakukannya revitalisasi produk wisata dan daya preferensi mengunjungi

TABEL 4.4

MATRIKS KORELASI ANTAR SUB VARIABEL REVITALISASI PRODUK WISATA TERHADAP PREFERENSI MENGUNJUNGI LEMBAH BOUGENVILLE RESORT

\begin{tabular}{|l|l|l|l|l|}
\hline & \multicolumn{1}{|c|}{$\mathrm{Y}$} & \multicolumn{1}{c|}{$\mathrm{X} 1$} & \multicolumn{1}{c|}{$\mathrm{X} 2$} & \multicolumn{1}{c|}{$\mathrm{X} 3$} \\
\hline $\mathrm{Y}$ & 1 & 0,193 & 0,134 & 0,155 \\
\hline $\mathrm{X} 1$ & 0,193 & 1 & 0,165 & 0,260 \\
\hline $\mathrm{X} 2$ & 0,134 & 0,165 & 1 & 0,222 \\
\hline $\mathrm{X} 3$ & 0,155 & 0,260 & 0,222 & 1 \\
\hline
\end{tabular}

\section{Uji Keseluruhan (Uji F) / Simultan}

Berdasarkan kerangka teori yang menyatakan bahwa terdapat pengaruh revitalisasi produk wisata terhadap preferensi mengunjungi, lebih lanjut akan diuji secara keseluruhan melalui Uji-F sebagai berikut:

TABEL 4.5 UJI KESELURUHAN (UJI F)

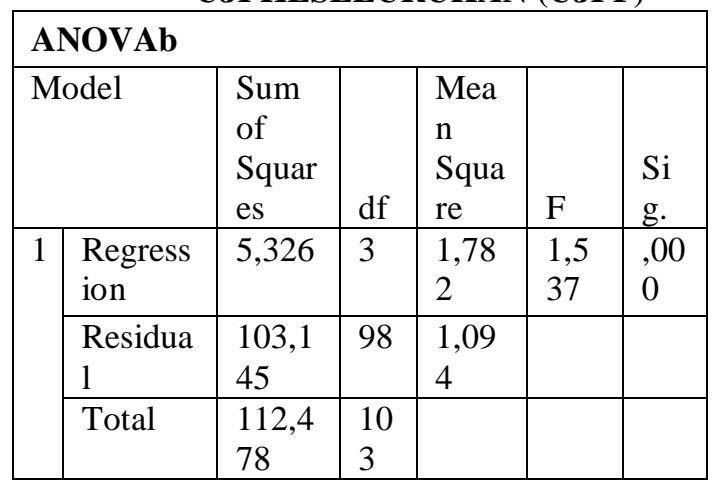

Sumber: Pengolahan Data 2011

Berdasarkan hasil pengujian untuk uji F melalui program SPSS 18.0 (Tabel Anova) diperoleh data pengujian keseluruhan pada Tabel Anova menunjukkan bahwa $F_{\text {hitung }}>F_{\text {tabel }}$ yaitu 1, 537> 1,39 dengan tingkat signifikan (sig) sama dengan 0,000. atau lebih kecil dari 0,05 , sehingga dapat diambil kesimpulan bahwa Ho ditolak. Oleh karena itu,secara keseluruhan model fit dan bisa dilakukan uji secara parsial.

\section{Uji Parsial}

Selanjutnya adalah pengujian secara parsial dengan melihat koefisien korelasi jalur $\mathrm{X}$ terhadap Y dengan kriteria keputusan untuk pengujian koefisien jalur sebagai berikut:

TABEL 4.6

HASIL PENGUJIAN KOEFISIEN JALUR

\begin{tabular}{|l|l|l|l|l|l|}
\hline \multicolumn{2}{|l|}{$\begin{array}{l}\text { Koefisien } \\
\text { Jalur }\end{array}$} & $\mathrm{t}_{\text {tabel }}$ & $\mathrm{t}_{\text {hitung }}$ & $\mathrm{Sig}$ & $\begin{array}{l}\text { Keputusa } \\
\mathrm{n}\end{array}$ \\
\hline $\mathrm{P}_{\mathrm{yx} 1 .}$ & 0,35 & 1,6 & 2,90 &, 00 & Ho \\
1 & 2 & 7 & 6 & 7 & ditolak \\
\hline $\mathrm{P}_{\mathrm{yx} 1 .}$ & 0,42 & 1,6 & 1,82 &, 00 & Ho \\
2 & 4 & 7 & 7 & 4 & ditolak \\
\hline $\mathrm{P}_{\mathrm{yx} 1 .}$ & 0,31 & 1,6 & 1,70 &, 00 & Ho \\
3 & 4 & 7 & 0 & 0 & ditolak \\
\hline
\end{tabular}

Sumber: Pengolahan data 2011

Berdasarkan Tabel di atas dapat dilihat bahwa X1, X2, dan X3 memiliki nilai $t_{\text {hitung }}>t_{\text {tabel }}$ dengan tingkat signifikansi $<0,05$, sehingga terdapat pengaruh $\mathrm{X}$ yang terdiri dari $\mathrm{X} 1, \mathrm{X} 2$, dan X3 terhadap Y. 
3. Perhitungan Besarnya Pengaruh Revitalisasi produk Wisata terhadap Preferensi Mengunjungi

Untuk mengetahui pengaruh langsung dan tidak langsung revitalisasi produk wisata terhadap preferensi mengunjungi disajikan dalam tabel berikut:

\section{TABEL 4.7}

\section{HASIL PENGUJIAN KOEFISIEN JALUR, PENGARUH LANGSUNG DAN TIDAK \\ LANGSUNG DARI REVITALISASI PRODUK WISATA TERHADAP PREFERENSI MENGUNJUNGI}

\begin{tabular}{|c|c|c|c|c|c|}
\hline \multirow[b]{2}{*}{$X$} & \multirow{2}{*}{$\begin{array}{c}\text { Pengaruh } \\
\text { Langsung } \\
\text { Terhadap } \\
\text { Y }\end{array}$} & \multicolumn{3}{|c|}{$\begin{array}{c}\text { Pengaruh tidak } \\
\text { Langsung } \\
\text { Melalui } \\
\end{array}$} & \multirow{2}{*}{$\begin{array}{c}\mathrm{R}^{2} \\
\mathrm{Y}_{\mathrm{X} 1}, \\
\ldots, \mathrm{Y}_{\mathrm{X}} \\
3\end{array}$} \\
\hline & & X1 & $\mathrm{X} 2$ & X3 & \\
\hline $\mathrm{X} 1$ & 0,124 & - & $\begin{array}{l}0,0 \\
25\end{array}$ & $\begin{array}{l}0, \\
02 \\
9 \\
\end{array}$ & 0,177 \\
\hline $\mathrm{X} 2$ & 0,098 & $\begin{array}{l}0,02 \\
9\end{array}$ & - & $\begin{array}{l}0, \\
03 \\
0\end{array}$ & 0,157 \\
\hline X3 & 0,180 & $\begin{array}{l}0,02 \\
5\end{array}$ & $\begin{array}{l}0,0 \\
30\end{array}$ & - & 0,234 \\
\hline $\mathrm{R}^{2}$ & & & & & 0,568 \\
\hline
\end{tabular}

Sumber: Pengolahan data 2011

Tabel 4.7 tersebut berarti bahwa terdapat pengaruh yang signifikan antara revitalisasi produk wisata yang terdiri dari atraksi wisata, amenitas dan aksesibilitasterhadap preferensi mengunjungi Lembah Bougenville Resort.Dimana semakin tinggi pelaksanaan revitalisasi produk wisata maka tingkat preferensi mengunjungi semakin tinggi, dan juga sebaliknya.

Hal ini berdasarkan pendapatNindyo Suwarno (2008:414) pengembangan revitalisasi suatu kawasan yang meliputi analisis produk wisata dapat mempengaruhi minat wisatawan untuk mengunjungi suatu tujuan wisata.

Dimensi-dimensi revitalisasi produk wisata yang memiliki pengaruh terbesar terhadap preferensi mengunjungi adalah aksesibilitas yang berpengaruh langsung sebesar 0,180pengaruh tidak langsung melalui atraksi wisata sebesar 0,025 melalui amenitas sebesar 0,030.Penolakan terhadap hipotesis didukung dengan fakta yang ada di lapangan bahwa revitalisasi produk pada preferensi mengunjungi.
Pengunjung yang datang ke Lembah Bougenville Resort rata-rata memiliki tujuan untuk menghilangkan segala perasaan penat, bosan, stress, akibat rutinitas sehari-hari mereka, dan dengan berkunjung ke Lembah Bougenville Resort mereka mengaharapkan dapat merubah segala perasaan tersebut menjadi perasaan yang ceria, semangat, dan gembira. Lembah Bougenville Resort memberikan pengalaman menarik kepada pengunjung.

Pengalaman yang pengunjung harapkan saat mereka menikmati produk yang ditawarkan adalah pengalaman yang menyentuh perasaan, sehingga pengalaman tersebut akan melekat di benak pengunjung dan sulit untuk dilupakan, dan dapat menciptakan kesenangan pada pengunjung.

\section{Pengaruh Variabel Lain}

Berdasarkan hasil perhitungan di atas dapat diketahui bahwa pengaruh revitalisasi produk wisataterhadap preferensi adalah mengunjungisebesar 0.568sedangkan koefisien jalur variabel lain di luar variabel revitalisasi produk wisata yang terdiri dari atraksi wisata, amenitas dan aksesibilitas, ditentukan melalui:

$$
\begin{aligned}
P_{Z \varepsilon} & =\sqrt{1-R_{Y(X 1 \ldots \ldots \ldots X)}^{2}} \\
& =\sqrt{1-0.568} \\
& =0,657
\end{aligned}
$$

Hal tersebut berarti bahwa $\mathrm{X}_{1}$ sampaiX $_{3}$ bersama-sama mempengaruhi kepuasan pengunjung sebesar $72,40 \%$ dan sisanya sebesar $(0,657)^{2}=0,432 \times 100 \%=$ $43,2 \%$ dipengaruhi faktor lain yang tidak masuk ke dalam penelitian ini. Variabel lain di luar penelitian yang dapat mempengaruhi preferensi mengunjungi, antara lain: promosi yang dilakukan pihak Lembah Bougenville Resort belum dilakukan secara maksimal.

\subsection{Implikasi Hasil Temuan Penelitian} 4.4.1 Temuan Penelitian Bersifat Teoritik

1. Berdasarkan hasil temuan di atas, penulis memperkuat dengan konsep jurnal Jonny Wongso revitalisasi menurut Departemen Kimpraswil (2002) adalah rangkaian upaya menghidupkan kembali kawasan yang cenderuang mati, meningkatkan nilai-nilai vitalitas yang strategis dan signifikan dari kawasan yang masih mempunyai potensi 
dan mengendalikan kawasan yang cenderung kacau atau semrawut.

2. Berdasarkan hasil temuan, peneliti memperkuat dengan menggunakan teori preferensi yang dikemukakan Nicholson (2004:208) mengungkapkan bahwa: Preferensi wisatawan sangat dipengaruhi oleh tingkat kepuasan/kesenangan (utilitas) yang akan diterima karena keputusan/pilihan yang mereka buat. Keberadaan hambatan akan membuat wisatawan cenderung berupaya untuk memaksimalkan utilitas yang akan mereka terima dalam tingkat pengorbanan yang sama. Preferensi wisatawan adalah gambaran-gambaran dari nilai-nilai terbaik yang dipertimbangkan wisatawan dalam menentukan sebuah pilihan. Selain itu, preferensi juga mampu membentuk sebuah perilaku yang lebih mengarah pada sikap atau respon atas sebuah produk wisata.

3. Berdasarkan hasil penelitian ini, terdapat pengaruh yang signifikan antara revitalisasi produk wisata terhadap preferensi mengunjungi. Penulis memperkuat dengan menurut jurnalNindyo Suwarno (2008:414) pengembangan revitalisasi suatu kawasan yang meliputi analisis produk wisata dapat mempengaruhi minat wisatawan untuk mengunjungi suatu tujuan wisata yang terdiri dari tiga dimensi yaitu revitalisasi atraksi wisata, revitalisasi amenitas dan revitalisasi aksesibilitas.

\subsection{Temuan Penelitian Bersifat Empirik}

Berdasarkan hasil pengujian yang telah dilakukan maka terdapat hasil temuan yang bersifat empirik, yaitu:

1. Revitalisasi produk wisata yang terdiri dari revitalisasi atraksi wisata, revitalisasi amenitas dan revitalisasi aksesibilitas. Sub variabel yang memperoleh penilaian tertinggi adalah pada revitalisasi amenitas.

2. Preferensi mengunjungi yang terdiri dari lokasi, aksesibilitas, fasilitas, suasana, pelayanan dan kemampuan karyawan bahwa sub variabel yang memperoleh penilaian tertinggi adalah fasilitas.

Berdasarkan temuan tersebut bahwa terdapat penemuan yang menarik dari sebelum dan sesudah dilakukannya revitalisasi produk wisata. Pengunjung Lembah Bougenville Resort cenderung menyukai perbaikan yang terjadi pada amenitas yang merupakan sub variabel yang memiliki penilaian tertinggi namun pengunjung cenderung kurang menyukai harga khususnya pada harga makanan dan harga kamar. Dengan adanya revitalisasi produk wisata yang dilakukan Lembah Bougenville Resort ternyata mampu memberikan penilaian pengunjung terhadap harga.

Temuan inidapat diyakini bahwa penelitian penulis mampu memberikan sumbangsih ilmiah bagi pengembangan ilmu pengetahuan manajemen pemasaran pariwisata, khususnya manajemen destinasi wisata mengenai revitalisasi produk wisata dan preferensi, serta sebagai bahan pertimbangan bagi pihak Lembah Bougenville Resort dalam melaksanakan program pemasaran di Lembah Bougenville Resort.

\section{KESIMPULAN DAN} REKOMENDASI

\subsection{Kesimpulan}

Berdasarkan kajian teori, hasil penelitian, dan pengujian path analysis yang dilaksanakan mengenai analisis revitalisasi produk wisata terhadap preferensi mengunjungi Lembah Bougenville Resort,dapat disimpulkan sebagai berikut:

1. Gambaran mengenai revitalisasi produk wisata yang dilaksanakan di Lembah Bougenville Resort sebelum dilakukan revitalisasi maupun sesudah dilakukan revitalisasi mendapat penilaian yang bervariatif dari pengunjung Lembah Bougenville Resort.

- Gambaran mengenai sebelum dilakukannya revitalisasi produk wisata di Lembah Bougenville Resort yang mendapatkan penilaian tertinggi menurut pengunjung adalah amenitas, amenitas dirasakan pengunjung baik karena amenitas yang ditawarkan masih dirasakan baru sama seperti lembah Bougenville Resort yang baru didirikan. Penilaian terendah sebelum dilakukannya revitalisasi produk wisata adalah aksesibilitas. Aksesibilitas dirasakan kurang baik oleh pengunjung karena jalur yang dilalui menuju Lembah Bougenville Resort sangat sederhana. 
- Gambaran mengenai setelah dilakukannya revitalisasi produk wisata di Lembah Bougenville Resort yang mendapatkan penilaian tertinggi menurut pengunjung Lembah Bougenville Resort adalah atraksi wisata. Atraksi wisata yang sudah direvitalisasi memberikan daya tarik tertentu kepada pengunjung untuk dijadikan sebagai preferensi mengunjungi Lembah Bougenville Resort. Penilaian terendah menurut pengunjung setelah dilakukannya revitalisasi produk wisata di Lembah Bougenville Resort adalah amenitas. Pengunjung merasakan bahwa amenitas yang ditawarkan cenderung dirasakan pengunjung tidak banyak mengalami revitalisasi terutama mengenai harga yang dirasakan pengunjung sehingga kurang menjadi preferensi mengunjungi Lembah Bougenville Resort.

2. Gambaran preferensi mengunjungi Lembah Bougenville Resort yang tertinggi adalah fasilitas, fasilitas yang ditawarkan Lembah Bougenville Resort dirasakan dapat menarik perhatian pengunjung untuk menjadikan fasilitas sebagai preferensi mengunjungi lembah Bouggenville Resort. Sedangkan preferensi mengunjungi yang terendah adalah pelayanan di Lembah Bougenville Resort.

3. Secara keseluruhan berdasarkan pengujian hipotesis menunjukan revitalisasi produk wisata yang terdiri dari atraksi wisata, amenitas dan aksesibilitas memberikan pengaruh yang signifikan terhadap preferensi mengunjungi Lembah Bougenville Resort. Untuk dimensi aksesibilitas merupakan dimensi yang paling tinggi berpengaruh terhadap preferensi mengunjungi Lembah Bougenville Resort setelah dilakukannya revitalisasi produk wisata. Sedangkan yang memiliki pengaruh terendah adalah amenitas. Pengunjung cenderung menyukai amenitas yang ada namun cenderung tidak menyukai harga yang ditawarkan.

\subsection{Rekomendasi}

Berdasarkan penelitian yang telah dilakukan dan temuan yang telah diperoleh, maka penulis mencoba memberikan saran seperti hal-hal berikut:
1. Revitalisasi yang diterapkan di Lembah Bougenville Resort yang terdiri dari dimensi atraksi wisata, amenitas dan aksesibilitas. Ketiga dimensi tersebut aksesibilitas merupakan dimensi yang paling berpengaruh dirasakan pengunjung sedangkan yang terendah adalah dimensi amenitas. Hal ini harus diperhatikan oleh pihak Lembah Bougenville Resort. Pihak Lembah Bougenville Resort harus terus melakukan program-program yang dapat menarik minat pengunjung untuk mengunjungi Lembah Bougenville Resort. Pada Amenitas yang perlu diperhatikan adalah pada harga dan jenis menu yang ditawarkan. Harga pada cottage dan pada menu makanan sebaiknya lebih disesuaikan dan jenis menu yang ditawarkan lebih bervariatif disesuaikan dengan segmentasi pengunjung.

2. Ketiga dimensi revitalisasi produk wisata yang terdiri dari atraksi wisata, amenitas dan aksesibilitas terbukti dapat mempengaruhi preferensi pengunjung untuk mengunjungi Lembah Bougenville Resort

3. Saran penulis untuk dapat meningkatkan preferensi mengunjungi Lembah Bougenville Resort adalah meningkatkan produk wisata yang ditawarkan kepada pengunjung yang terdiri dari atraksi wisata, amenitas dan aksesibilitas termasuk hal-hal lainnya seperti pelayanan dan pihak Lembah Bougenville Resort harus lebih bekerjasama dengan pihak lain. Pihak Lembah Bougenville Resort sebaiknya melakukan kerjasama dengan pihak-pihak yang berhubungan dengan kegiatan yang terdapat di Lembah Bougenville Resort.

a. Pihak Pemerintahan

Sektor publik atau pemerintahan dalam hal ini merupakan pihak terkait yang sangat penting karena dengan adanya kerjasama yang baik aksesibilitas, perijinan dan promosi dapat dilakukan antara pihak Lembah Bougenville Resort dengan pihak pemerintahan.

b. Sektor Swasta

Lembah Bougenville Resort harus bekerjasama dengan pihak swsata karena pihak swasta cukup berperan, pihak swasta dapat membangun tempat-tempat yang dapat menunjang 
dan menarik pengunjung untuk dating ke kawasan Lembang khususnya Desa Cibodas.

4. Berdasarkan penelitian ini penulis menyadari masih banyak terdapat kelemahan seperti pengetikan yang salah dan pengkajian teori mengenai pengembangan produk wisata yang masih belum lengkap beserta teori pendukungnya. Untuk itu diharapkan agar peneliti selanjutnya dapat mengkaji lebih luas mengenai revitalisasi produk wisata secara mendalam dan pengaruh harga terhadap preferensi mengunjungi Lembah Bougenville Resort.

\section{DAFTAR PUSTAKA}

Ali Hasan. 2008. Marketing.Jakarta : Media Pressindo.

Asep Hermawan. 2006. Penelitian Bisnis Paradigma Kuantitatif. Jakarta: Gramedia Widia Sarana Indonesia

Basu Swastha. 1990. Azas-azas Marketing. Yogyakarta: Liberty

Gamal Suwantoro. 2004. Dasar-dasar Pariwisata. Yogyakarta:Andi

George E. belch dan Michael A.2007. Advertising and Promotion

Graffin.R. W.2001.Business $8^{\text {th }}$ Edition. New Jersey: Prentice Hall

Fandy Tjiptono, Gregorius Chandra dan Dadi Adrian. 2008. Pemasaran strategik. Yogyakarta:Andi

I Gede Iwan Suryadi.2007. Metode Riset Bisnis. Jakarta: Gramedia Pustaka Utama

Ismayanti. 2010. Pengantar Pariwisata. Jakarta: Grasindo

Kotler, Philip dan Gary Amstrong. 2008. Principles of Marketing. USA and Keller Kevin Lane. 2009. Marketing Management 13th edition. New Jersey: Prentice Hall

Muljadi A.J. 2009. Kepariwisataan dan Perjalanan. Jakarta: PT. Raja Grafindo Persada

Nyoman S. Pendit .1999. Pengantar Ilmu Pariwisata. Jakarta: PT. Pradnya Paramita

Oka a. Yoeti. 1996. Pemasaran Pariwisata Terpadu. Bandung:Angkasa. 2002. Pemasaran Pariwisata

Terpadu. Bandung:Angkasa.
2004. Perencanaan \& Pengembangan Pariwisata.Jakarta : PT Pradnya Paramita. 2009. Pemasaran Pariwisata Terpadu. Bandung:Angkasa.

Philip dan Duncan. 2001. British and Irish paintings in public collections

Sihite Richard. 2000. Tourism Industry. Surabaya. SIC

Prof. Dr. I Gde Pitana dan I Ket ırya Diarta. 2009. Pengantar ¿'lmu Pariwisata. Yogyakarta: Andi.

Rambat Lupiyodi \& A Hamdani.2006. Manajemen Pemasaran Jasa. Jakarta. Salemba Empat

Schiffman, Kanuk \& Leslie Lazar Kanuk. 2000. Perilaku Konsumen. Jakarta: PT Indeks

Sudibyo. 2002. Perilaku Konsumen dan Kesinambungan Kebutuhan. Jakarta: Gramedia Pustaka Utama

Sutisna. 2004. Perilaku Konsumen dan komunikasi Pemasaran. Bandung: Rosda Karya

Sugiyono. 2009. Metode Penelitian Bisnis. Bandung: Alfabeta

Suharsimi Arikunto (2009:145) Prosedur Penelitian, Suatu Pendekatan Praktek (Edisi revisi 5) Jakarta:Rineka Cipta

Uma sekaran. 2007. Metodologi Penelitian Untuk Bisnis. Jakarta.Salemba Empat

Undang-Undang No.10 Tahun 2009 Tentang Kepariwisataan

Weaver, David \& Laura Lawton. 2006. Tourism Management. Third Edition. Australia: jhon Wiley \& Sons Australia, Ltd.

\section{JURNAL}

Annisa Anastasia. (2009). Pengaruh Preferensi Wisatawan Terhadap Keputusan Berkunjung ke Objek Wisata Alam di Kawasan Bandung Selatan

I Made wardana. (2007). Revitalisasi Konsep Structure-Conduct-Performance

Pemasaran Internal dan Budaya Organisasi dalam Meningkatkan Kinerja Pemasaran Jasa Pariwisata

Jonny Wongso. (2006). Strategi Revitalisasi Kawasan Pusat Kota Bukit tinggi

Leo Huang. 2006. Rural Tourism Revitalization of The Leasure Farm Industry Farm by Implementing an Ecommerce Strategy 
Much.Djunaidi. (2006). Penilaian Kualitas Jasa Pelayanan Lembaga Bimbingan Belajar Primagama Berdasarkan Preferensi Konsumen

Nindyo Suwarno. (2008). Revitalisasi Kawasan Candi Bororbudur, Magelang, Jawa Tengah

Olvini Ttyssia.(2010).Pengaruh Diferensiasi Produk Terhadap preferensi Konsumen dalam Pembelian

Rochajat Harun. (2008). Objek \& Atraksi Wisata

Suparno Saputra, SE.,MM. (2010). Pengaruh Diferensiasi Produk Terhadap Preferensi Konsumen dalam Pembelian

Ruxandra Irina Popescu, Razvan-Andrei Corbos. (2009). The Marketing Mix Contribution In Improving The National Museum Of Romanian History Strategy

Ted Mininni. (2008). Brandchannel. Kinds of Revitalization

Wright, Pamela A. (2007). North American Ecotourism Markets: Motivations, Preferences, and Destination. Journal of Sage Publications, 2455 Teller road, TousandOaks, CA 91320, USA. Pg.7.

Yulianto. (2005). Preferensi Konsumen dalam Memilih Maskapai Penerbangan Rute Surabaya Jakarta

Yulia. V. Smirnova. (2006). Strategy Revitalization Product

\section{WEBSITE}

Www.google.com

www.bps.com

www.bandungtourism.com

www.kabupatenbandungbarat.go.id

http://lembahbougenville.com

http://search.ebschohost.com

www.nulibrary.com

http://books.google.co.id

www.zibs.com 
Kariza Devia Gantini, HP. Diyah Setiyorini

Tourism and Hospitality Essentials (THE) Journal, Vol.II, No.2, 2012 - 406 